Вісник Житомирсъкого державного иніверситети імені Івана Франка. Педагогічні науки. Bun. 4 (103)

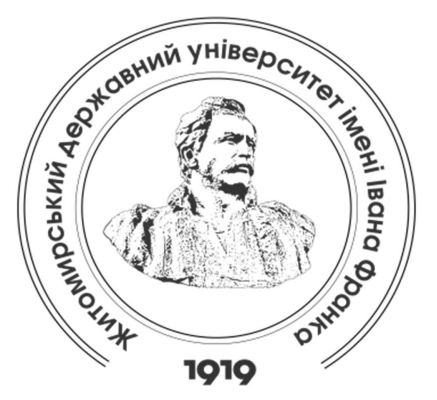

Zhytomyr Ivan Franko State University Journal. Pedagogical Sciences. Vol. 4 (103)

Вісник Житомирського державного університету імені Івана Франка. Педагогічні науки. Вип. 4 (103)

ISSN (Print): 2663-6387

ISSN (Online): 2664-0155

UDC $37.01 / .09 .111 .004+378(045)$
DOI $10.35433 /$ pedagogy.4(103).2020.61-68

\title{
BENEFITS OF DIGITAL LEARNING APPLICATION AT UNIVERSITIES
}

\section{N. M. Vasylyshyna*}

The main goal of ongoing paper is to emphasize on the top priority benefits dealt with the urgent modern time issue such as digitalization and computerization of the educational process at higher educational institutions. The background of the survey states that the use of information technology facilitates and improves learning process, activates and stimulates the mental activity of students and allows to diversify and increase its efficiency. The main findings of the survey can be summed up in three blocks. Firstly, we have presented plenty of definitions of the term "digital learning", which not only differ in their formulation and the terms used, but also, in some cases, they have opposite, sometimes narrower focus. To add, the present study shows various definitions: Dutch, Portugal, Serbia, Serbia and Austrian. Secondly, the results were connected with general overview of five competences, such as: information and data literacy, communication and collaboration, digital content creation, protecting personal data and privacy, problem solving. identifying digital competence gaps. Thirdly, the ten sufficient benefits of digital learning have been identified as well. They were titled in the following way: personalized learning, expanded learning opportunities, high engagement learning, competencybased learning, collaborative learning, quality learning products, relevant and regularly updated content learning, next-gen learning for educators. The uniqueness of the research findings is approved with: the broad multi-exemplifications of the term definition "digital learning" in different countries; the presentation of more precise term substitute "one-to-one technologyenhanced learning"; the provision of the key digital learning competences and benefits among the great number of the in the scientific researches. Moreover, we must mention that proper consideration and application of all five competences and ten benefits of digital learning in the higher education process will: improve students' motivation, accountability; help them to become more engaged in the process, more interested in growing their knowledge base; assist them to acquire problem-solving skills and familiarity with emerging technologies. In particular, the practical value of digital learning skills is of a great assistance during learning English, using numerous on-line digital free available sources.

Key words: digital learning, challenges, technologies, one-to-one technology-enhanced learning, five competences, benefits, high school educators.

\footnotetext{
${ }^{*}$ Candidate of Pedagogical Sciences (PhD in Pedagogy), Associate Professor

(National Aviation University, Kyiv)

filologyN@gmail.com
}

ORCID: 0000-0002-0003-9998 


\section{ПЕРЕВАГИ ЗАСТОСУВАННЯ ЦИФРОВОГО НАВЧАННЯ В УНIВЕРСИТЕТАХ}

\section{Н. М. Васимишина}

Основні висновки накової розвідки можна підсумувати у трьох блоках. По-перше, ми представили безліч визначень терміну "ииррове навчання", які не лише відрізняються між собою формулюваннями, але також, в деяких випадках, вони мають протилежну, а іноді вужиу спрямованість. До того ж, у иьому дослідженні наведено приклади різних тлумачень ключового поняття "цифрове навчання": голландське, португальське, сербське, та австрійське. По-друге, додаткові отримані результати стосувалися аналізу п'яти компетентностей, таких як: інформаиійна грамотність, спілкування та співпраия, створення иифрового контенту, захист персональних даних $i$ конфрідениійності, вирішення проблем та виявлення прогалин у иифровій компетентності. По-трете, у ході наукової роботи також були сформульовані десять важливих переваг иифрового навчання, а саме: персоналізоване навчання, навчання із більшими можливостями, навчання з високим рівнем залучення до активної розумової діяльності, компетентнтністе навчання, взаємонавчання, навчання із постійно оновлюваним змістом, навчання для викладачів майбутнього покоління. Унікальність результатів дослідження пояснюеться: багатоаспектністю тлумачення терміна "иифрове навчання" у різних країнах; формулюванням більш точного поняття-замінника "індивідуальне технологічне навчання"; виокремленням ключових компетентностей та переваг иифрового навчання серед великої кількості, мають місие у сучасних наукових дослідженнях. Більше того, варто зазначити, що належний розгляд, застосування всіх n'яти компетениій та десяти переваг ииррового навчання у навчальному проиесі вищоі освіти: покращить мотивацію студентів, ӥхню відповідальність; допоможе ӥм бути більи активними у навчальному проиесі; мотивуватиме їх до самовдосконалення; сприятиме розвитку вмінь критичного мислення; сприятиме підвищенню технологічної грамотності. Крім того, особливої практичної значущості иифрові вміння набувають під час вивчення англійської мови он-лайн.

\footnotetext{
Ключові слова: ииррове навчання, суперечності, технологї̈, індивідуальне технологічне навчання, п'ять компетентностей, переваги, викладачі вищої школи.
}

Introduction of the issue. Digital technologies have revolutionized our society, and children today grow up and live in a world where these are ubiquitous. Moreover, digital technologies affect all aspects of life: from healthcare to commerce, from social interactions to the way people work. Education systems are no less affected, not only because technology can impact the way education is delivered, but also because education has a role to play in preparing young people for a tech-driven world [5].

Moreover, as research has long shown, growing up in the digital age does not make "digital natives", inherently competent and confident with digital technologies. Researches indicate, in fact, that the use of technology is to a great extent restricted to non-school, leisure time activities, while engagement with technology for educational purposes in school lags behind $[5 ; 7]$.

Digital education strategies, monitoring and implementation, the continuous and increasing digitalization in society, as well as changes in technology itself, results in strategies and policies becoming rapidly out of date.

European countries need to continually review and develop new strategic policies and measures to meet the new demands for high quality digital education. Therefore, virtually all education systems currently have strategies for digital education [5;7].

Current state of the issue. It worth mentioning that interactive learning methods have a strong impact on the 
learning outcomes from the point of view of numerous scientists.

According to Shuler, there is emerging interest among scientists in acquiring knowledge about how interactive technology affects the learning achievements of high school students [12].

Clements, Sarama indicated that the implementation of technology in education promotes student-centered learning practices, which developmental theorists support for early childhood education above more didactic teaching style [12].

Blackwell states that traditional didactic teaching styles differ from student-centered learning in that the focus of instruction shifts from the teacher to the student. The main focus of student-centered learning is that the student develops autonomy and independence by making the student responsible for its own learning path [12].

The meta-analysis of Habler, Major and Hennessy supports the view that students' learning outcomes will improve when gaining knowledge via education is assisted by technology. In their study, literature reporting the use of tablets for education by primary and secondary school students is reviewed. The aim was to determine if, when and how using tablets in school might impact on learning outcomes. Among twelve highly methodological trustworthy studies that are reviewed, nine studies report positive learning outcomes and three studies report no difference in learning outcomes when children were assisted by tablets. Thus, the majority of the included studies report positive learning outcomes while using tablets for educational purposes, and the affordances of the tablet appeared to be a relevant factor for these results $[10 ; 12]$.

However, none of the reviewed studies examined whether the learning outcomes improved more with the help of a tablet when comparing them to the learning outcomes of a control group, in which children got education via traditional teaching methods. The majority of the reviewed studies only compared students' knowledge before extra practice with tablets to their knowledge after extra practice with tablets.

Riconscente, for example, investigated whether the iPad game Motion Math would improve fouth graders' knowledge of fractions. The results show that their knowledge test scores improved by playing the game for 20 minutes daily over a 5-day period, when comparing the results to a control group that only had regular mathematics instruction without target on fractions. The control group is therefore not representative and comparable to students who learned fractions each day over a 5-day period [12].

Fernandez-Lopez, Rodriguez-Fortiz, Rodriguez-Almendros and MartinezSegura also found positive learning outcomes when using their learning platform Picaa on mobile devices like the iPhone or the iPad. However, they also did not compare their findings to a control group and their platform was specifically developed for students with special educational needs [12].

The study of Furio, GonzalezGancedo, Juan, Segui and Costa examined learning outcomes educators, by comparing the use of an educational game on an iPhone to a tablet. Their results show that the mobile device that is used is not a decisive factor for learning outcomes. They also had no control group for learning via traditional teaching methods $[4 ; 10$; 12].

Outline of unresolved issues brought up in the article. Despite the numerous findings in the area of digital learning, this problem is very broad and complicated.

Consequently, we have initiated this brief constructive analysis to display main professional competences which 
are to be mastered and shaped in modern student by means of information technologies usage.

From our perspective, such digital skills, knowledge and vocational abilities will make future professionals more competitive, smart and required in their employment areas within globalization processes.

Aim of the research. Considering the urgency and actuality of the digital education application in modern teaching process, we can identify the main purposes of the research that are: the first part of the paper is dedicated to figuring out European and national definitions of digital competence; the second part of the paper is grounded on the description of the five competence areas; the third part of the ongoing pedagogical investigation reveals ten sufficient benefits taken from digital learning active usage at universities.

Results and discussion. The challenges posed by and the potential benefits of digital education in school are manifold. From a labor-market perspective, there is a skills gap to fill, as an increasing number of jobs require a high level of proficiency in the use of technologies and many new jobs are based on specialized digital skills. From a social point of view, the challenge is one of inclusiveness: a digital divide between those with no or only basic digital skills, and others with higher level skills could widen existing gaps in society and further exclude some parts of the population. From an educational point of view, the challenge is not only to ensure that young people develop the digital competences needed, but also to reap the benefits from the pedagogical use of technology [3; 5].

European and national definitions of digital competence. At European level, digital competence has long been acknowledged and defined as one of the key competences for lifelong learning, initially appearing in the 2006 Recommendation.

In the latest edition of May 2018, digital competence is defined as the confident, critical and responsible use of, and engagement with, digital technologies for learning, work, and for participation in society. A comprehensive framework describing the competence in more detail was first published in 2013 and later updated [3; $5 ; 11]$.

Also, in several other countries, the national definitions not only differ in their formulation and the terms used but also, in some cases, they have a different, sometimes narrower focus (table 1).

European and National Definitions of Digital Competence

\begin{tabular}{|l|l|}
\hline \multicolumn{1}{|c|}{ Country } & \multicolumn{1}{|c|}{ Definition } \\
\hline Dutch & $\begin{array}{l}\text { The Dutch definition stated in the curriculum refers to four } \\
\text { areas: basic information and communication technology } \\
\text { skills, information skills media awareness and } \\
\text { computational thinking. In comparison with the European } \\
\text { key competence definition, there is therefore more focus } \\
\text { on media awareness and computational thinking [5]. }\end{array}$ \\
\hline Portugal & $\begin{array}{l}\text { In Portugal, definition of digital competence includes the } \\
\text { notion of digital literacy as well as the production of new } \\
\text { knowledge through research. It is narrower than the } \\
\text { European key competence definition and the concepts of } \\
\text { safety, digital wellbeing and intellectual property rights are } \\
\text { absent. However, in essentials skils and in citizenship } \\
\text { education, these are included in compulsory school } \\
\text { curricula [5]. }\end{array}$ \\
\hline
\end{tabular}

Table 1 


\begin{tabular}{|c|c|}
\hline Serbia & $\begin{array}{l}\text { In Serbia, the definition from the national digital } \\
\text { competence framework puts the accent on the pedagogical } \\
\text { use of technology. Digital competence refers to a set of } \\
\text { knowledge, skills, attitudes, abilities and strategies } \\
\text { necessary for effective use of information and } \\
\text { communication technologies and digital media. It seeks to } \\
\text { ensure deliberate, flexible and safe use of the technologies, } \\
\text { as well as improving the teaching and learning process } \\
\text { and activities in both on- and off-line environments [5], } \\
\text { [7]. }\end{array}$ \\
\hline France & $\begin{array}{l}\text { In France, digital competence is defined along two lines. } \\
\text { The first refers to it as a language: programming } \\
\text { languages and algorithms. The second refers to it as a } \\
\text { tool, namely to use digital technologies to search and } \\
\text { access information and to produce digital content [5], [11]. }\end{array}$ \\
\hline Austria & $\begin{array}{l}\text { The Austrian basic digital education encompasses } \\
\text { digital literacy, media literacy and political literacy. } \\
\text { Teaching digital competences enables pupils to select, } \\
\text { reflect upon and apply suitable tools and methods for } \\
\text { specific scenarios in an academic, professional and private } \\
\text { context on the basis of a broad overview of current digital } \\
\text { tools. The acquisition of competences in the field of digital } \\
\text { technologies is always done in a reflective way and also } \\
\text { bears in mind the prerequisites and consequences, } \\
\text { advantages and disadvantages and social effects of the use } \\
\text { of technology [3], [5], [8]. }\end{array}$ \\
\hline
\end{tabular}

Furthermore, having reviewed various international definitions related to digital competence elements, we are able to come up with our definition of information literacy of modern specialist. So, the information literacy is the availability of digital knowledge and skills for:

- the right information identification needed to perform a particular task or solution

to a certain problem;

- the effective search of information, its interpretation and analysis, evaluation

- reliability, including observance of ethical norms and rules of use of the received

data;

- the information transmition and presentation of the results of its analysis to other co-workers in a form convenient for them;
- the information application to achieve necessary results, including obtaining of the new knowledge and extensive education.

In the frame of our investigation, term to define the use of interactive technology for education is one-to-one technology-enhanced learning. In general, the term technology-enhanced learning is used to refer to learning supported by interactive technology. It covers all those circumstances where technology plays a significant role in making learning more effective, efficient or enjoyable. The notion of one-to-one refers to a ratio of at least one computing device for each student [12].

Deep research analysis has outlined the existence of five competences that are included at high education level in terms of explicit learning outcomes in the curricula of European education systems. 
Competence area \#1. "Information and data literacy". Evaluating data, information and digital content. This competence requires learners to analyse, compare and critically evaluate the credibility and reliability of sources of data, information and digital content. $[3 ; 5]$.

Competence area \#2. "Communication and collaboration". This competence refers to the use of digital tools and technologies for collaborative processes, and for the co-construction and cocreation of data, resources and knowledge. Collaboration or teamwork is an educational objective that often appears in national curricula and in relation to many different activities.

The related learning outcomes in national curricula mention "working together in an online environment" as well as "using digital tools and collaborative shared documents". Other concepts include digital communities, online learning communities or virtual communities and a collaborative online environment, digitally mediated communities of practice, group problem solving with the use of technologies and using collaborative applications for cocreating, co-developing digital materials [5].

Competence area \# 3. "Digital content creation". This competence requires learners to create and edit digital content in different formats and to express themselves through digital means [7].

Competence area \# 4. "Protecting personal data and privacy". This competence requires learners to: protect personal data and privacy in digital environments; understand how to use and share personally identifiable information while being able to protect themselves and others from damage; and understand that digital services have a 'privacy policy' to inform users how personal data is used.

Competence area \# 5. "Problem solving. Identifying digital competence gaps". This competence requires learners to: understand where their own digital competences need to be improved or updated; be able to support others in developing digital competences; seek opportunities for self-development; keep up-to-date with digital evolution $[5 ; 11]$.

The shift from print to digital is a profound transition in how human beings learn, it is more significant than the development of the printing press and its benefits are spreading much more quickly. Like the printing press six centuries ago, this transition is transforming formal education and spreading informal learning opportunities.

Digital learning is powering seven benefits that are changing the opportunity set for teachers. There are three additional benefits that are proving to be game changers for educators.

Benefit \# 1. Personalized Learning. The opportunity to help every student learn at the best pace and path for them is the most important benefit of digital learning. Hundreds of next generation schools are prototyping the benefits of customization. A diverse group of 28 practitioners, advocates, and business and union leaders recently came together to reimagine education given the new opportunity of digital learning. They noted that personalized, relevant and contextualized learning can increasingly be tailored based on the learner's own passions, strengths, needs, family, culture, and community [12].

Benefit \#2. Expanded Learning Opportunities. Digital learning is extending learning opportunities worldwide. Access to full and part-time online learning means that every student, state policy permitting, has access to many world languages, college preparatory curriculum, and advanced studies. It is remarkable that thousands of university courses by the best professors are available for free to 
anyone with a broadband connection [12].

Benefit \#3. High Engagement Learning. The shift to digital can boost student motivation. Anyone who has witnessed the engagement of game-based learning can appreciate the potential to create learning experiences that boost persistence [12].

Benefit \#4. Competency-Based Learning. Students show what they know and progress based on demonstrated mastery. Competencybased learning is possible in paper and pencil, but it is hard to monitor and manage an individual progress model at scale $[10 ; 12]$.

Benefit \#5. Assessment for learning. Digital learning powers continuous feedback from content-embedded assessment, games, simulations, and adaptive learning. When student can track their own progress it can improve motivation and agency [4; 12].

Benefit \#6. Collaborative Learning. Digital learning powers collaboration. Social learning platforms like Edmodo make it easy for teachers to create and manage groups. Collaborative authoring environments like Google Docs make it easy for teams to co-author documents and presentations [1;12].

Benefit \# 7. Quality Learning Products. Digital learning tools allow students to produce professional quality products and to share them with public audiences. Presentation, publications, and portfolios change the classroom culture from turn-it-in, to production for public audiences. Also, digital tools mean more and better writing $[1 ; 12]$.

Benefit \#8. Sharing economy. There has been an explosion of free and open content and tools. Schools can save money while ensuring equitable access. Common standards and sharing platforms have made it possible for millions of educators to share tools and resources across state lines $[1 ; 2 ; 12]$.

Benefit \#9. Relevant and Regularly Updated Content. Regardless of age or content, students have more access to relevant and regularly updated content. Next generation instructional systems that include print and digital options with online adaptive skill building allow teachers and students to personalize in new and exciting ways. The ability to update easily, means access to updated material and features on a regular basis $[4 ; 6 ; 9 ; 12]$.

Benefit \#10. Next-Gen Learning for Educators. Blended, personalized and competency-based learning is for educators too! Preparation and development are increasingly based on a competency map, many personalized ways to learn, and multiple opportunities to demonstrate learning. Teachers can also join online professional learning communities, like teachability, to ask questions and share tips and stay connected with a global community $[2 ; 4 ; 6]$.

Conclusions and research perspectives. To sum up, the theoretical analysis of the research of a stated problem has suggested the implications for using digital learning in higher education. This thesis provided eye-opening insights to the existing literature on the use of interactive technology for educational purposes. Three important implications can therefore be derived from this study's findings.

First of all, the interactivity of technology does not guarantee better learning outcomes. This study revealed that application of an interactive learning motivated students to learn, but not led to better learning outcomes than less interactive learning methods.

Secondly, successful integration of technology in classrooms nowadays is not hindered by attitudes of students or teachers.

However, digital learning methods will only be added to existing education systems if they have an added value for both the teachers and the students.

And last but not least, the role of teachers in achieving desirable learning 
outcomes continuous to be a central factor in when more technology is implemented to existing education. Students can achieve worse learning outcomes during the tablet or computer learning sessions, because they do not receive any guidance or feedback from a teacher.

Furthermore, listed in the research benefits of digital learning application has witnessed that technological methods can make learning process more effective, increasing the total skills results.

Limitations and recommendations of this thesis' study explain that when conducting further research considerable aspect is the survey that was conducted to test students' attitudes towards interactive technology. Future research could therefore also focus on students of various professional training.

Another aspect that should be examined in future research are extra learning conditions. This study only focused on the definition, competence arear and benefits of digital learning, but the following surveys ought to discuss the digital learning methods, such as methods developed for laptops or desktop computers to see if there are any differences between all of them.

In this way, better conclusions can be drawn about the effect of using interactive technology for educational purposes. Regardless of these limitations, the present study showed that continuous research and improvements will always be required to provide the most qualitative and effective education for the high education students.

\section{REFERENCES}

1. Chan, T.W., Roschelle, J., Hsi, S., Kinshuk, Sharples, M., Brown, T., \& Soloway, E. (2006). Oneto-one technology-enhanced learning: An opportunity for global research collaboration. Research and Practice in Technology Enhanced Learning, 1 (1), 329 [in English].

2. Collins, A., \& Halverson, R. (2009). Rethinking education in the age of technology: the digital revolution and schooling in America. New York: Teachers College Press. 3-12 [in English].

3. Council recommendation of 22 May 2018 on key competences for lifelong learning. (2018). 1-13 [in English].

4. Daniëlle Hendriks. (2016). Comparing traditional and digital learning methods to improve the learning outcomes of young children. Tilburg University, 5-18 [in English].

5. Digital Education at School in Europe. Eurydice Report. (2019). Luxembourg: Publications Office of the European Union, 9-45 [in English].

6. Dix, A., Finlay, J., Abode, G., \& Beale, R. (2004). Human Computer Interaction (3rd ed.). London, England: Pearson Education Limited, 345-515 [in English].

7. Education and Training. ec.europa.eu. Retrieved from https://ec.europa.eu/education/node_ en [in English].

8. EU data protection rule. ec.europa.eu. Retrieved from https://ec.europa.eu/info/law/lawtopic/data-protection/eu-dataprotection-rules_en [in English].

9. Five digital resources for autonomous English language practice. www.britishcouncil.org. Retrieved from https://www.britishcouncil.org/voicesmagazine/five-digital-resourcesautonomous-english-language-practice [in English].

10. Online education vs Traditional Education: Which one is better for you? www.classgap.com. Retrieved from https://www.classgap.com/en/blog/on line-education-traditional-educationwhich-one-better-for [in English].

Received: October 29, 2020 Accepted: December 03, 2020 